Australian Journal of

Crop Science

AJCS 12(04):617-623 (2018)

doi: 10.21475/ajcs.18.12.04.pne902

\title{
Changes in competitive ability between safflower-weeds affected by timing of nitrogen fertilizers
}

\author{
Reza Moradi Talebbeigi ${ }^{1}$, Seyed Abdolreza Kazemeini ${ }^{*}$, Hossein Ghadiri \\ Department of Crop Production and Plant Breeding, School of Agriculture, Shiraz University, Iran \\ "Corresponding author: kazemin@shirazu.ac.ir
}

\begin{abstract}
Nitrogen $(\mathrm{N})$ effects on crop-weed competition and its information may help to improved integrated weed management systems. A 2year field experiment (2015 and 2016) was conducted on a silty clay loam soil in semi-arid climatic conditions to determine the combined effects of $N$ sources (ammonium nitrate (AN), ammonium sulfate (AS), sulfur coated urea (SCU), urea (U)) and timing fertilization (sowing, stem elongation, flowering) on weed-safflower (Carthamus tinctorius L.) competition and safflower yield at Shiraz University, Iran. The experimental design was a split split-plot with three replications. Results showed that weeds significantly reduced safflower yield components approximately $39 \%$ and caused a decrease in seed yield up to $70 \%$. In weed free, the highest seed yield $\left(3303.52 \mathrm{~kg} \mathrm{ha}^{-1}\right)$ and oil yield (753.09 $\left.\mathrm{kg} \mathrm{ha}^{-1}\right)$ were achieved by AN and $\mathrm{U}$ fertilizers, respectively, when $\mathrm{N}$ fertilization was applied half $\left(50 \mathrm{~kg} \mathrm{~N} \mathrm{ha}^{-1}\right)$ at sowing and other half $\left(50 \mathrm{~kg} \mathrm{~N} \mathrm{ha}^{-1}\right)$ at stem elongation and zero $\mathrm{N}$ application at flowering stage $\left(\mathrm{T}_{1} \mathrm{~N}^{1} / 2, \mathrm{~T}_{2} \mathrm{~N}^{1} / 2\right.$, and $\mathrm{T}_{3} \mathrm{~N}_{0}$ ). However, $A \mathrm{~N}$ or $\mathrm{U}$ fertilizer timing of $\mathrm{T}_{1} \mathrm{~N}^{1} / 2, \mathrm{~T}_{2} \mathrm{~N} 1 / 2$, and $\mathrm{T}_{3} \mathrm{~N}_{0}$ increased relative competition intensity (RCl) and ability to withstand competition (AWC) indices approximately $80 \%$. On the contrary, $U$ fertilizer timing of $T_{1} N^{1} / 2, T_{2} N^{1} / 2$, and $T_{3} N_{0}$ increased ability to compete (AC) index up to $20 \%$ as compared to the $A N$ fertilizer. Our research has shown that $U$ fertilizer timing of one third of the $\mathrm{N}\left(33.5 \mathrm{~kg} \mathrm{~N} \mathrm{ha}^{-1}\right)$ fertilization at sowing, two thirds of the $\mathrm{N}\left(66.5 \mathrm{~kg} \mathrm{~N} \mathrm{ha}^{-1}\right)$ fertilization at stem elongation and zero $\mathrm{N}$ application at flowering $\left(\mathrm{T}_{1} \mathrm{~N}^{1} / 3, \mathrm{~T}_{2} \mathrm{~N}^{2} / 3\right.$, and $\left.\mathrm{T}_{3} \mathrm{~N}_{0}\right)$ can be used to advise farmers of the importance of strategic fertilizer management in terms of both weed management and safflower yield.
\end{abstract}

Keywords: Ammonium nitrate; Competition indices; Fertilization management; Seed yield.

Abbreviations: AN_ammonium nitrate; AS_ammonium sulfate; SCU_sulfur coated urea; U_urea; RCI_relative competition intensity, AWC_ability to withstand competition; AC_ability to compete; N_Nitrogen.

\section{Introduction}

Oilseeds are of great value in nutritional demands of mankind, animal feeding and medicine. Of them, safflower produces high quality oil, being one of the safest crop oils (Mundel et al., 2004; Bergman and Kandel, 2013). Safflower response to $\mathrm{N}$ is generally greater than other nutrients. However, $\mathrm{N}$ fertilizer sources play a significant role in maximizing the quality and quantity of oilseeds. Osman et al. (2014) showed that AN fertilizer increases growth and yield parameters of oilseed rape (Brassica napus L.) as compared to the other $\mathrm{N}$ fertilizer sources. Ozturk (2010) found that $U$ fertilizer gave higher crop yield than AN fertilizer. Muharnmad et al. (2007) reported that the highest seed protein was obtained when oilseed rape was by calcium ammonium nitrate (CAN). Rathke et al. (2005) found that mineral $\mathrm{N}$ fertilization (CAN fertilizer) versus cattle manure slurry application and influence the productivity of winter oilseed rape resulted in lower oil content and higher crude protein content. Timing of $\mathrm{N}$ fertilization is another important aspect to ensure nutrient availability when crops need it (Cheema et al., 2010). Narits (2010) showed that the highest seed and oil yields of oilseed rape were obtained by split AN fertilizer treatment (40 kg ha ${ }^{-1}$ at the beginning of spring vegetation, $40 \mathrm{~kg} \mathrm{ha}^{-1}$ at stem elongation, and $40 \mathrm{~kg} \mathrm{ha}^{-1}$ at flowering) of $120 \mathrm{~kg} \mathrm{ha}^{-1}$. Sheibani and Ghadiri (2012) observed that half of the $\mathrm{N}\left(152 \mathrm{~kg} \mathrm{U} \mathrm{ha}^{-1}\right)$ application at the sowing time and the other half at the end of rosette stage of oilseed rape enhanced grain yield up to $35 \%$.

Because weeds are often better able to exploit $\mathrm{N}$ fertilizer than agricultural crops, proper use of $\mathrm{N}$ fertilization strategies is required to optimize crop yield (Dordas and Sioulas, 2008) and reduce weed infestation (Johnson et al., 2007). Research has shown that weed growth can be affected by $\mathrm{N}$ fertilizer sources and also may alter the crop-weed competitive interactions (Davis and Liebman, 2001). Redroot pigweed (Amaranthus retroflexus L.) seed germination was stimulated by 10 to $100 \mathrm{ppm}$ of AN or U fertilizer sources (Sardi and Beres, 1996). Paschke et al. (2000) found that the addition of mineral $\mathrm{N}$ to disturbed rangelands increased the relative abundance of cheat grass (Bromus secalinus L.). Several lines of research suggest that low early-season $\mathrm{N}$ levels could result in selective weed suppression. Early-season soil $\mathrm{N}$ levels are kept 
intentionally low in a split application management system because crop demand for $\mathrm{N}$ at this time is low, whereas the potential for loss of excess $\mathrm{N}$ from the system is high (Liebman and Davis, 2000; Blackshaw et al., 2004). Amy et al. (2008) found that emergence of sown giant foxtail increased as $\mathrm{N}$ application rate increased, particularly at the early $\mathrm{N}$ application date, but the influence of $\mathrm{N}$ on weed emergence is dependent on the weed species, and environmental conditions. Thus, most researchers agree that the management of $\mathrm{N}$ should be tailored to optimize use efficiency and reduce weed interference (Benech-Arnold et al., 2000; Berger et al., 2007; Blackshaw and Brandt, 2008). Sheibani and Ghadiri (2012) reported weed biomass increased significantly when all $\mathrm{N}$ fertilizer ( $304 \mathrm{~kg} \mathrm{U} \mathrm{ha}^{-1}$ ) was used at the end of rosette stage of oilseed rape. Terry et al. (2012) found that high rate of urea ammonium nitrate (UAN) application at early season of growth increased the competitive effects of weed in corn (Zea mays L.).

So, greater knowledge of split $\mathrm{N}$ sources effects on weed growth and competitive interactions with safflower will allow for a better understanding and would aid the development of fertilization strategies for the better weed control as components of integrated weed management programs. Therefore, in order to realize the maximum potential of the safflower quality and quantity and weed suppression, this study was conducted to determine the combine effects of $\mathrm{N}$ sources and timing pattern of fertilization on weed control, competitive ability safflower, yield and its components.

\section{Results}

\section{Safflower yield and yield components}

Safflower yield quality and quantity was significantly $(p<0.01)$ influenced by all treatments. In both years, the lowest yield response of safflower was observed in weedy condition (Table 1). In weedy condition, AN fertilizer timing of $T_{1} \mathrm{~N}^{1} / 3, \mathrm{~T}_{2} \mathrm{~N}^{2} / 3_{3}$, and $\mathrm{T}_{3} \mathrm{~N}_{0}$ maximized seed yield, whereas $U$ fertilizer timing of $\mathrm{T}_{1} \mathrm{~N}^{1} / 2, \mathrm{~T}_{2} \mathrm{~N}^{1} / 2$, and $\mathrm{T}_{3} \mathrm{~N}_{0}$ caused a decrease in seed yield up to $30 \%$ compared to AN fertilizer and similar timing pattern. Furthermore, AN fertilizer timing of $\mathrm{T}_{1} \mathrm{~N}^{1} / 3, \mathrm{~T}_{2} \mathrm{~N}^{2} / 3$, and $\mathrm{T}_{3} \mathrm{~N}_{0}$ increased oil yield to $153.45 \mathrm{~kg} \mathrm{ha}^{-1}$, but the highest protein yield ( $\left.58.78 \mathrm{~kg} \mathrm{ha}^{-1}\right)$ and biological yield $\left(3348.96 \mathrm{~kg} \mathrm{ha}^{-1}\right)$ were obtained with timing pattern of $\mathrm{T}_{1} \mathrm{~N}^{1} /{ }_{4}, \mathrm{~T}_{2} \mathrm{~N}^{3} / 4$, and $\mathrm{T}_{3} \mathrm{~N}_{0}$, while $\mathrm{U}$ fertilizer and similar timing pattern increased harvest index (Table 1). Similarly, in weed free the highest seed yield $\left(3303.52 \mathrm{~kg} \mathrm{ha}^{-1}\right)$, protein yield $\left(695.95 \mathrm{~kg} \mathrm{ha}^{-1}\right)$, biological yield $\left(8443.60 \mathrm{~kg} \mathrm{ha}^{-1}\right)$ and harvest index (39.14\%) were achieved by AN fertilizer timing of $\mathrm{T}_{1} \mathrm{~N}^{1} / 2, \mathrm{~T}_{2} \mathrm{~N}^{1} / 2$, and $\mathrm{T}_{3} \mathrm{~N}_{0}$. However, the highest oil yield $\left(753.09 \mathrm{~kg} \mathrm{ha}^{-1}\right.$ ) was observed by $\mathrm{U}$ fertilizer and similar timing pattern. Furthermore, AS or SCU fertilizer timing of $\mathrm{T}_{1} \mathrm{~N}^{1} / 3, \mathrm{~T}_{2} \mathrm{~N}^{1} / 3$, and $\mathrm{T}_{3} \mathrm{~N}^{1} / 3$ increased safflower yield and yield components to a lesser extent (Table 1 ). In weed free, increasing capitulum number tended to enhance seed yield, but seed yield was slowly declined in weedy condition as capitulum number (70 per $\mathrm{m}^{2}$ ) increased to more than (Fig.1a). Furthermore, seed yield maximized in weedy condition as seeds increased to more than 40 per capitulum, but in weed free increasing seed number up to 80 per capitulum maximized seed yield (Fig.1b). Similarly, seed yield increased as seed 1000 weight increased. In weedy condition, seed yield increased as seed 1000 weight increased to more than 25 g progressively. On the contrary, seed yield increased in weed free as seed 1000 weight increased to more than 39 g gradually (Fig.1(c)).

\section{Weed interference}

Results showed competition indices were significantly $(p<0.01)$ influenced by $\mathrm{N}$ sources, timing patterns and their interactions. Applying $A N$ or $U$ fertilizer and timing pattern of $T_{1} N^{1} / 2$, $\mathrm{T}_{2} \mathrm{~N}^{1} / 2$, and $\mathrm{T}_{3} \mathrm{~N}_{0}$ increased $\mathrm{RCl}$ index up to $80 \%$, while $\mathrm{RCl}$ index was reduced approximately $13 \%$ by $U$ fertilizer timing of $\mathrm{T}_{1} \mathrm{~N}^{1} /{ }_{3}, \mathrm{~T}_{2} \mathrm{~N}^{2} / 3$, and $\mathrm{T}_{3} \mathrm{~N}_{0}$ compared to $\mathrm{AN}$ fertilizer and similar timing pattern (Table 2). Furthermore, the highest AWC index (79.81\%) was obtained by AN fertilizer timing of $\mathrm{T}_{1} \mathrm{~N}^{1} / 2, \mathrm{~T}_{2} \mathrm{~N}^{1} / 2$, and $\mathrm{T}_{3} \mathrm{~N}_{0}$, but $\mathrm{U}$ fertilizer application and similar timing pattern reduced $\mathrm{AWC}$ up to $30 \%$. On the contrary, $\mathrm{RCl}$ and $\mathrm{AWC}$ increased to a lesser extent by SCU or AS fertilizers. The lowest $\mathrm{RCl}(40.80 \%)$ and AWC (18.45\%) indices were achieved by SCU fertilizer timing of $\mathrm{T}_{1} \mathrm{~N}^{1} /{ }_{3}, \mathrm{~T}_{2} \mathrm{~N}^{2} / 3$, and $\mathrm{T}_{3} \mathrm{~N}_{0}$ and $\mathrm{T}_{1} \mathrm{~N}^{1} / 2, \mathrm{~T}_{2} \mathrm{~N}^{1} / 2$, and $\mathrm{T}_{3} \mathrm{~N}_{0}$, respectively (Table 2). Ammonium Nitrate fertilizer timing of $T_{1} N^{1} / 2, T_{2} N^{1} / 2$, and $T_{3} N_{0}$ reduced safflower $A C$ index versus (vs.) weeds. Applying $U$ fertilizer and timing pattern of $\mathrm{T}_{1} \mathrm{~N}^{1} / 3, \mathrm{~T}_{2} \mathrm{~N}^{2} / 3$, and $\mathrm{T}_{3} \mathrm{~N}_{0}$ increased safflower $A C$ index vs. weeds so that increased rate of safflower $A C$ index vs. redroot pigweed and field bindweed was approximately $3 \%$, vs. common lambsquarters was $17.8 \%$, and vs. wild safflower was $10.5 \%$. Also, safflower $A C$ index vs. redroot pigweed maximized by SCU fertilizer and timing pattern of $\mathrm{T}_{1} \mathrm{~N}^{1} / 2, \mathrm{~T}_{2} \mathrm{~N}^{1} / 2$, and $\mathrm{T}_{3} \mathrm{~N}_{0}$, while timing pattern of $\mathrm{T}_{1} \mathrm{~N}^{1} / 3, \mathrm{~T}_{2} \mathrm{~N}^{1} / 3$, and $\mathrm{T}_{3} \mathrm{~N}^{1} / 3$ and similar $\mathrm{N}$ source maximized safflower $\mathrm{AC}$ vs. common lambsquarters and wild safflower. However, safflower $A C$ vs. field bindweed was maximized by AS fertilizer timing of $\mathrm{T}_{1} \mathrm{~N}^{1} / 3, \mathrm{~T}_{2} \mathrm{~N}^{1} / 3$, and $\mathrm{T}_{3} \mathrm{~N}^{1} / 3$ (Table 2).

\section{Discussion}

In weed free, our results showed that applying $\mathrm{AN}$ and/or $\mathrm{U}$ and timing pattern of $\mathrm{T}_{1} \mathrm{~N}^{1} / 2, \mathrm{~T}_{2} \mathrm{~N}^{1} / 2$, and $\mathrm{T}_{3} \mathrm{~N}_{0}$ fertilizer sources are able to stimulate safflower growth by means of an enlarged leaf canopy and a greater rate of leaf expansion, which increases light interception and enhances photosynthesis, resulting in more capitulum as compared to the other $\mathrm{N}$ fertilizer sources. These results are in agreement with those Osman et al. (2014), who reported that in oilseed rape, seed yield is closely related to the number of capitulum per plant and the physiological restrictions to capitulum formation are related to poor crop growth and limited leaf expansion. Bagavan and Ravikumar (2001) reported a positive correlation between number of capitulum per plant and safflower seed yield. Johnson et al. (2001) indicated that seed yield was positively correlated with safflower seed weight. Dordas and Sioulas (2008) reported that $\mathrm{N}$ fertilization increased seed yield by an average of $19 \%$, consequently increased the seed weight to $18 \%$, the number of capitulum 
Table 1. Effects of $\mathrm{N}$ sources and timing fertilization on seed yield $\left(\mathrm{kg} \mathrm{ha}^{-1}\right)$, oil yield $\left(\mathrm{kg} \mathrm{ha}^{-1}\right)$, protein yield $\left(\mathrm{kg}\right.$ ha $\left.{ }^{-1}\right)$, biological yield $(\mathrm{kg}$ $\left.\mathrm{ha}^{-1}\right)$, and harvest index (\%).

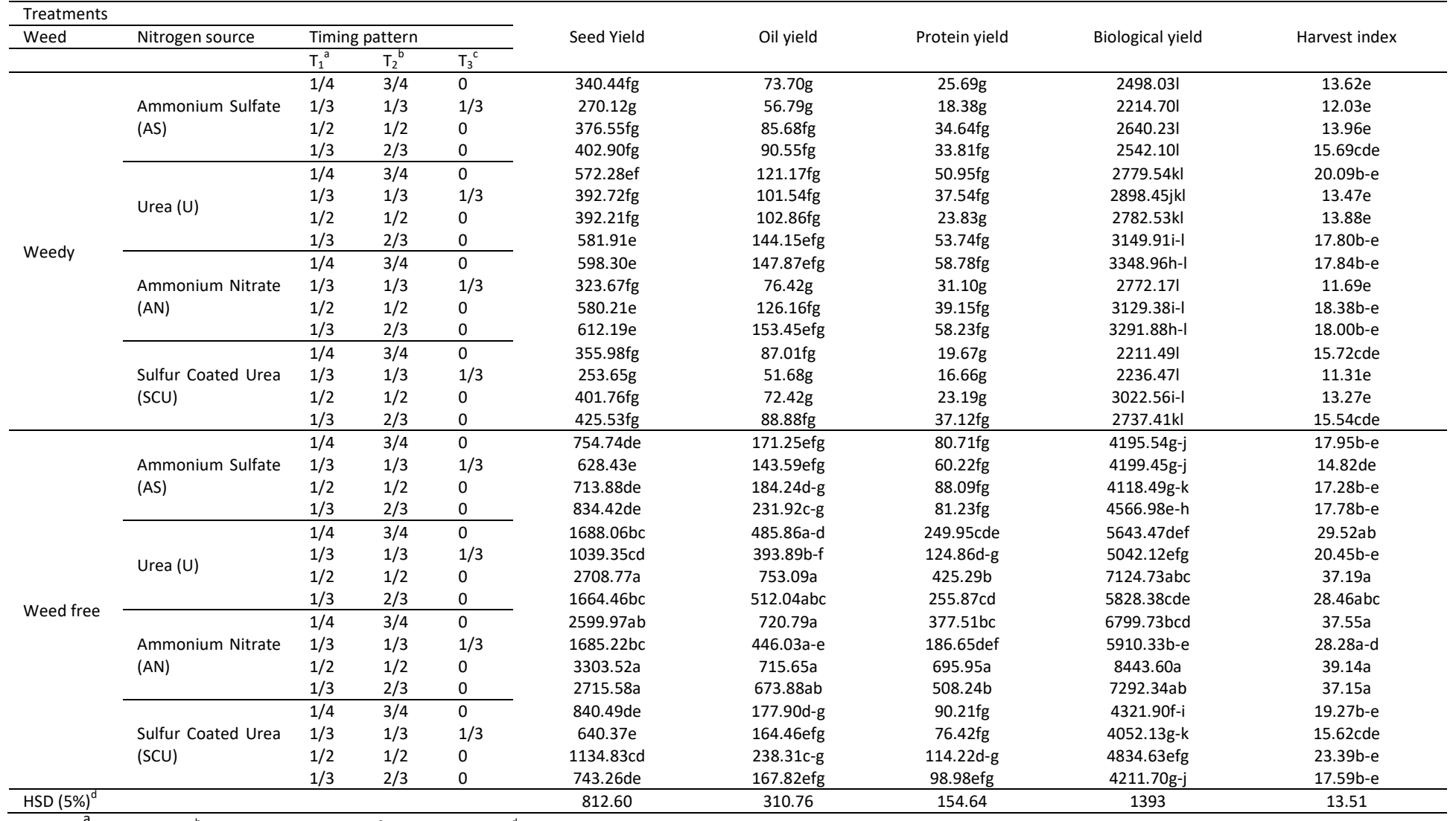

${ }^{\mathrm{a}}$ Sowing time, ${ }^{\mathrm{b}}$ Stem elongation stage, ${ }^{\mathrm{c}}$ Flowering stage, ${ }^{\mathrm{d}}$ Honest significant difference at $\mathrm{P}=0.05$.
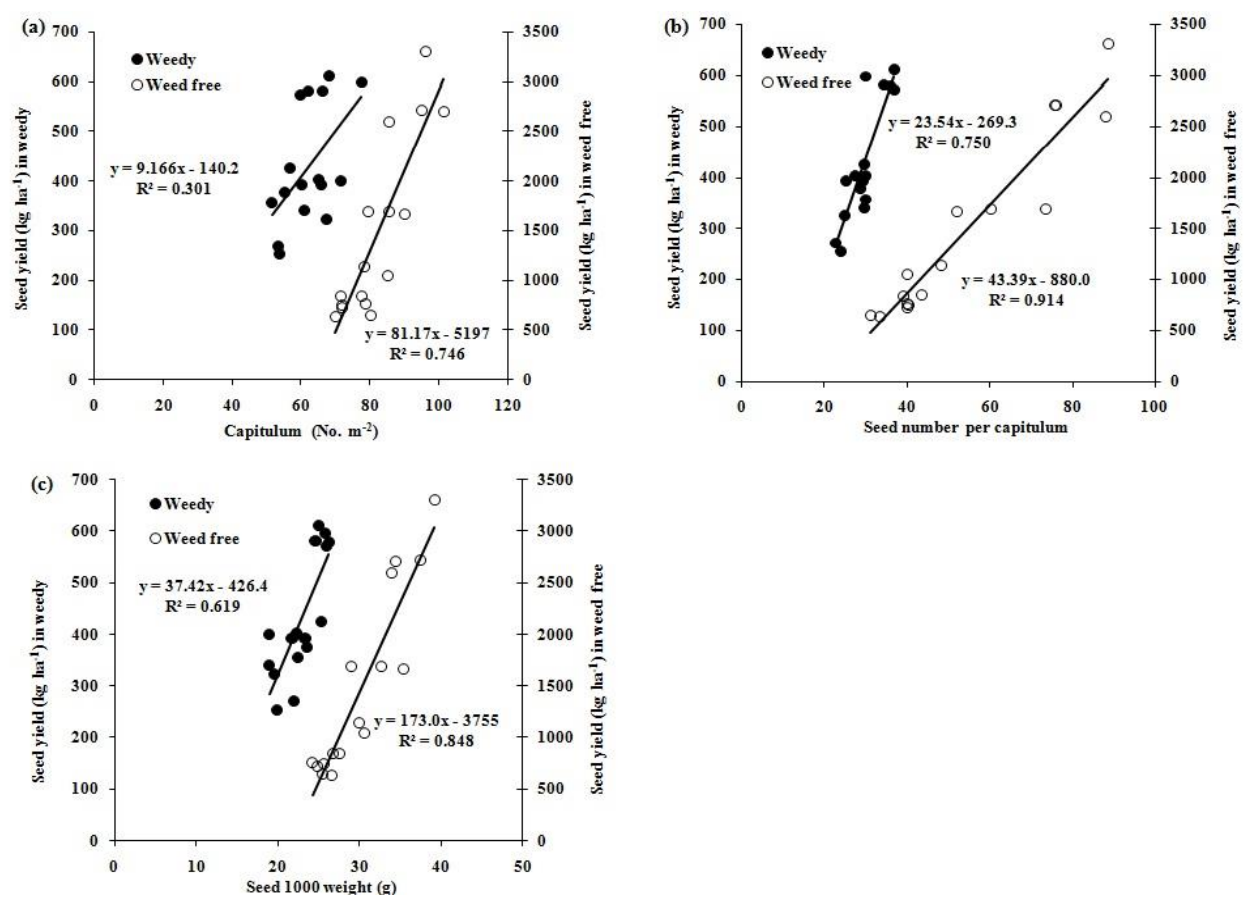

Fig 1. Correlation between safflower seed yield with capitulum number (a), seed number (b), and seed 1000 weight (c) under weedy and weed free condition. 
Table 2. Effects of $\mathrm{N}$ sources and timing fertilization on $\mathrm{RCI}(\%), \mathrm{AWC}(\%)$, and $\mathrm{AC}(\%)$ indices.

\begin{tabular}{|c|c|c|c|c|c|c|c|c|c|}
\hline \multicolumn{4}{|l|}{ Treatments } & \multirow{3}{*}{$\mathrm{RCl}^{\mathrm{e}}$} & \multirow{3}{*}{$A W C^{f}$} & \multicolumn{4}{|c|}{$A C^{g}$} \\
\hline \multirow[t]{3}{*}{ Nitrogen sources } & \multicolumn{3}{|c|}{$\begin{array}{l}\text { Timing } \\
\text { pattern }\end{array}$} & & & \multirow{2}{*}{$\begin{array}{c}\text { Safflower } \\
\text { vs. } \\
\text { Redroot } \\
\text { pigweed }\end{array}$} & \multirow{2}{*}{$\begin{array}{l}\text { Safflower vs. } \\
\text { Common } \\
\text { lambsquarters }\end{array}$} & \multirow{2}{*}{$\begin{array}{l}\text { Safflower } \\
\text { vs. Field } \\
\text { bindweed }\end{array}$} & \multirow[t]{2}{*}{$\begin{array}{c}\text { Safflower vs. Wild } \\
\text { safflower }\end{array}$} \\
\hline & $\mathrm{T}_{1}^{\mathrm{a}}$ & $\mathrm{T}_{2}^{\mathrm{b}}$ & $\mathrm{T}_{3}{ }^{\mathrm{c}}$ & & & & & & \\
\hline & $1 / 4$ & $3 / 4$ & 0 & 54.78de & $24.98 b c d$ & $11.98 a b c$ & $21.71 \mathrm{~cd}$ & 48.17def & $82.66 a b c$ \\
\hline Ammonium & $1 / 3$ & $1 / 3$ & $1 / 3$ & 51.79def & $38.09 b c$ & $13.08 \mathrm{abc}$ & $30.68 a$ & $61.57 a$ & $88.04 a b$ \\
\hline \multirow[t]{2}{*}{ Sulfate (AS) } & $1 / 2$ & $1 / 2$ & 0 & 46.82ef & $21.74 \mathrm{~cd}$ & $13.46 a b c$ & $22.62 \mathrm{~cd}$ & $51.94 \mathrm{bcd}$ & $78.87 \mathrm{bcd}$ \\
\hline & $1 / 3$ & $2 / 3$ & 0 & 46.39ef & $38.99 b c$ & $13.46 a b c$ & $28.97 a b$ & $50.28 \mathrm{cde}$ & $78.49 \mathrm{bcd}$ \\
\hline \multirow{4}{*}{ Urea (U) } & $1 / 4$ & $3 / 4$ & 0 & $65.59 \mathrm{~cd}$ & $47.54 a b c$ & $10.87 \mathrm{bc}$ & 20.70 cde & 40.78gh & $76.47 \mathrm{~cd}$ \\
\hline & $1 / 3$ & $1 / 3$ & $1 / 3$ & 61.11cde & $34.23 b c$ & $14.21 a b$ & $30.71 a$ & 45.46efg & $79.31 \mathrm{bcd}$ \\
\hline & $1 / 2$ & $1 / 2$ & 0 & $84.71 \mathrm{a}$ & $50.32 \mathrm{abc}$ & $11.45 a b c$ & $19.03 \mathrm{cde}$ & $37.57 \mathrm{hi}$ & $74.09 \mathrm{~cd}$ \\
\hline & $1 / 3$ & $2 / 3$ & 0 & $66.23 \mathrm{~cd}$ & 46.10abc & $11.41 \mathrm{abc}$ & 21.14cde & $41.52 \mathrm{gh}$ & $77.64 \mathrm{bcd}$ \\
\hline & $1 / 4$ & $3 / 4$ & 0 & $74.56 b c$ & $34.61 b c$ & $10.15 b c$ & 20.26 cde & 39.92gh & $78.38 \mathrm{bcd}$ \\
\hline Ammonium & $1 / 3$ & $1 / 3$ & $1 / 3$ & 79.90ab & $37.48 \mathrm{bc}$ & 11.33abc & $22.55 \mathrm{~cd}$ & $42.22 \mathrm{fgh}$ & $77.69 \mathrm{bcd}$ \\
\hline \multirow[t]{2}{*}{ Nitrate (AN) } & $1 / 2$ & $1 / 2$ & 0 & $82.12 a$ & $79.81 a$ & $8.06 c$ & $15.64 \mathrm{e}$ & $32.63 i$ & $62.62 \mathrm{e}$ \\
\hline & $1 / 3$ & $2 / 3$ & 0 & $75.79 b c$ & $54.74 a b$ & $11.11 \mathrm{abc}$ & $17.95 \mathrm{de}$ & 40.19gh & 70.24de \\
\hline & $1 / 4$ & $3 / 4$ & 0 & $55.24 \mathrm{de}$ & $44.14 b c$ & $12.51 \mathrm{abc}$ & $24.76 b c$ & $52.13 \mathrm{bcd}$ & $79.09 \mathrm{bcd}$ \\
\hline \multirow{3}{*}{$\begin{array}{l}\text { Sulfur Coated } \\
\text { Urea (SCU) }\end{array}$} & $1 / 3$ & $1 / 3$ & $1 / 3$ & $57.25 \mathrm{de}$ & $26.22 \mathrm{bcd}$ & 15.10ab & $31.14 a$ & 56.78ab & $90.80 a$ \\
\hline & $1 / 2$ & $1 / 2$ & 0 & $63.58 \mathrm{~cd}$ & $18.45 d$ & $15.92 \mathrm{a}$ & $23.91 b c$ & 49.50cde & $80.04 a b c d$ \\
\hline & $1 / 3$ & $2 / 3$ & 0 & $40.80 f$ & $21.59 \mathrm{~cd}$ & $15.34 \mathrm{ab}$ & $30.67 a$ & $55.36 \mathrm{abc}$ & 81.13abcd \\
\hline HSD (5\%) & & & & 42.95 & 34.58 & 5.58 & 5.87 & 6.44 & 11.29 \\
\hline
\end{tabular}

${ }^{\mathrm{a}}$ Sowing time, ${ }^{\mathrm{b}}$ Stem elongation stage, ${ }^{\mathrm{c}}$ Flowering stage, ${ }^{\mathrm{d}}$ Honest significant difference at $\mathrm{P} \leq 0.05 .{ }^{\mathrm{e}}$ Relative competition intensity, ${ }^{\mathrm{f}}$ Ability to withstand competition, ${ }^{\mathrm{g}}$ Ability to compete.

Table 3. Monthly weather summary during the safflower growing season from 2015 to 2016 at Shiraz, Iran.

\begin{tabular}{|c|c|c|c|c|c|c|c|c|c|}
\hline \multirow[t]{2}{*}{ Months } & \multicolumn{3}{|c|}{ Average temperatures $(\mathrm{O} C)$} & \multicolumn{3}{|c|}{ Precipitation $(\mathrm{mm})$} & \multicolumn{3}{|c|}{ Average relative humidity (\%) } \\
\hline & 2015 & 2016 & 30 Years & 2015 & 2016 & 30 Years & 2015 & 2016 & 30 Years \\
\hline April & 13.90 & 10.20 & 11.23 & 39.50 & 33.50 & 45.82 & 43.10 & 43.16 & 51.85 \\
\hline May & 17.60 & 17.30 & 16.15 & 10.00 & 0.50 & 11.70 & 34.56 & 33.81 & 48.41 \\
\hline June & 23.00 & 20.30 & 20.49 & 0.00 & 0.00 & 0.76 & 24.65 & 27.29 & 39.47 \\
\hline July & 26.00 & 25.29 & 25.43 & 0.00 & 0.00 & 0.30 & 24.48 & 25.31 & 37.49 \\
\hline Average/Total & 20.13 & 18.27 & 18.33 & 12.38 & 9.63 & 14.65 & 31.69 & 32.39 & 44.31 \\
\hline
\end{tabular}


per plant to $32 \%$, and the number of seeds per capitulum to $41 \%$, which was consistent with our results.

Whenever a crop emerges, weeds also appear. Certainly, competition for light, water, and nutrients is the major factors accounting for the adverse effect of weeds on crop growth and yield, so uncontrolled weeds can stunt crop growth (Zoschke and Quadranti, 2002). We found that AN fertilizer source and timing pattern of $\mathrm{T}_{1} \mathrm{~N}^{1} / 2, \mathrm{~T}_{2} \mathrm{~N}^{1} / 2$, and $\mathrm{T}_{3} \mathrm{~N}_{0}$ maximized yield response of safflower, this potentially have the unintended consequence of increasing the growth and competitive ability of weeds in weedy plots. It is believed that shifting the $\mathrm{N}$ source from the current $A N$ to AS or $U$ fertilizers would reduce weed infestations by inhibiting germination and radicle elongation (Mumera and Below, 1993; Liebman and Davis, 2000). Because weeds are often better able to exploit nutrients than agricultural crops, applying low early-season $\mathrm{N}$ levels can reduce weeds germination (DiTomaso, 1995; Benech-Arnold et al., 2000). Results of field experiments indicate that for certain crop-weed combinations, delaying soil $\mathrm{N}$ availability can shift the competitive balance to favor crop growth. In other words, timing patterns of $\mathrm{N}$ fertilizer that minimize $\mathrm{N}$ availability early in the growing season should reduce weed infestation (Davis and Liebman, 2001). Blackshaw et al. (2003) documented that $\mathrm{N}$ can markedly alter crop-weed competitive interactions and, depending on the weed species and density, $\mathrm{N}$ fertilizer can increase the competitive ability of weeds more than that of the crop, and crop yield remains unchanged or actually decreases in some cases.

\section{Materials and method}

\section{Experimental conditions}

A 2-year field experiment (2015 and 2016) was conducted at the experimental research station (Badjgah), Shiraz University $\left(52^{\circ} 46^{\prime} \mathrm{E}, 29^{\circ} 50^{\prime} \mathrm{N}\right.$ and $\left.1810 \mathrm{~m}\right)$, Iran. The soil was silty clay loam with a $\mathrm{pH}$ of 7.25 and an EC of $0.475 \mathrm{dS} \mathrm{m}^{-1}$. Total $\mathrm{N}$, mean phosphorus $(\mathrm{P})$ and mean potassium (K) were $0.07 \%, 12$ $\mathrm{mg} \mathrm{kg}$ and $250 \mathrm{mg} \mathrm{kg}^{-1}$, respectively. Monthly average temperature, rainfall, and relative humidity are shown for the time of the study and for the last 30 years (Table 3 ). The experiment was arranged as split split-plot based on randomized complete block design with three replications. The treatments consisted of two levels of weed control (weedy and weed free) as main plot, $\mathrm{N}$ fertilizer sources in four levels: ammonium nitrate (AN; $25 \% \mathrm{~N}$ ), ammonium sulfate (AS; $21 \%$ $\mathrm{N})$, sulfur coated urea (SCU; $34 \% \mathrm{~N})$, and urea $(\mathrm{U} ; 46 \% \mathrm{~N})$ as sub plot, and timing pattern of $\mathrm{N}$ was top-dressed (broadcast method) at three stages of safflower growing season $\left(\mathrm{T}_{1}=\right.$ Sowing, $T_{2}=$ Stem elongation, and $T_{3}=$ Flowering) and in four levels $\left(\mathrm{N}_{0}=\right.$ No $\mathrm{N}$ fertilization, $\mathrm{N} 1 / 2=$ Half of the $\mathrm{N}$ fertilization, $\mathrm{N} 1 / 3=$ One third of the $\mathrm{N}$ fertilization, $\mathrm{N} 1 / 4=$ One quarter of the $\mathrm{N}$ fertilization, $\mathrm{N}^{2} / 3=$ Two thirds of the $\mathrm{N}$ fertilization, and $\mathrm{N}^{3} / 4=$ Three quarters of the $\mathrm{N}$ fertilization) as sub sub-plots. Nitrogen requirement of the safflower (at a rate of $100 \mathrm{~kg} \mathrm{~N}$ $\mathrm{ha}^{-1}$ during growing season) was determined according to the soil test analysis. $\mathrm{T}_{1} \mathrm{~N}^{1} / 4, \mathrm{~T}_{2} \mathrm{~N}^{3} / 4$, and $\mathrm{T}_{3} \mathrm{~N}_{0}$ represent one quarter of the $\mathrm{N}\left(25 \mathrm{~kg} \mathrm{~N} \mathrm{ha}^{-1}\right)$ fertilization at sowing, three quarters (75 $\mathrm{kg} \mathrm{N} \mathrm{ha}^{-1}$ ) at stem elongation, and zero $\mathrm{N}$ application at flowering stage of the safflower, respectively. $\mathrm{T}_{1} \mathrm{~N}^{1} / 3, \mathrm{~T}_{2} \mathrm{~N}^{1} / 3$, and $\mathrm{T}_{3} \mathrm{~N}^{1} / 3$ represent one third of the $\mathrm{N}(33.3$ kg $\mathrm{N} \mathrm{ha}{ }^{-1}$ ) fertilization at sowing, stem elongation, and flowering stage, respectively. $T_{1} \mathrm{~N}^{1} / 2, \mathrm{~T}_{2} \mathrm{~N}^{1} / 2$, and $\mathrm{T}_{3} \mathrm{~N}_{0}$ represent half of the $\mathrm{N}\left(50 \mathrm{~kg} \mathrm{~N} \mathrm{ha}^{-1}\right)$ fertilization at sowing and other half $\left(50 \mathrm{~kg} \mathrm{~N} \mathrm{ha}^{-1}\right)$ at stem elongation and zero $\mathrm{N}$ application at flowering, respectively. $\mathrm{T}_{1} \mathrm{~N}^{1} / 3, \mathrm{~T}_{2} \mathrm{~N}^{2} /{ }_{3}$, and $\mathrm{T}_{3} \mathrm{~N}_{0}$ represent one third of the $\mathrm{N}\left(33.5 \mathrm{~kg} \mathrm{~N} \mathrm{ha}^{-1}\right)$ fertilization at sowing, two thirds of the $\mathrm{N}\left(66.5 \mathrm{~kg} \mathrm{~N} \mathrm{ha}^{-1}\right)$ fertilization at stem elongation and zero $\mathrm{N}$ application at flowering of the safflower, respectively. Land preparation practices included plowing, disking and ridging plots (sized 3 by $3 \mathrm{~m}$ ). Each plot was separated by two ridges to avoid cross contamination among plots. The seeds of safflower (Zendehrood cultivar) were sown two $\mathrm{cm}$ deep in rows spaced $15 \mathrm{~cm}$ apart (30 plant $\mathrm{m}^{-2}$ ) on March $25^{\text {th }}$ in 2015 and 2016 years. Triple super phosphate fertilizer was applied at the sowing time at a rate of $50 \mathrm{~kg} \mathrm{ha}^{-1}$ according to the soil test analysis. Other management practices, such as pest control, were conducted according to local agronomic practices unless otherwise indicated. In weed free plots, weeds were controlled by hand hoeing throughout the growing season. The irrigation period was set at 10 days for all treatments and field soil of plots was sampled at three depths $(30,60$ and $90 \mathrm{~cm})$ at the time of irrigation using the gravimetric method, and the percentage of moisture was determined and each plot was uniformly irrigated by siphon.

\section{Traits measurements}

At the end of growth period (approximately middle of July in both years), weeds and safflower samples were randomly hand harvested from the central $1 \mathrm{~m}^{2}$ of the middle rows in each plot after maturity. Predominant weed species were redroot pigweed, common lambsquarters (Chenopodium album L.), field bindweed (Convolvulus arvensis L.), and wild safflower (Carthamus oxycanthus L.). Weeds species were separated and then oven dried at $76{ }^{\circ} \mathrm{C}$ for $48 \mathrm{~h}$ and weighed. Then, relative competition intensity $(R C I)=\frac{(\mathrm{Y} \text { weed free- } \mathrm{Y} \text { weedy })}{\mathrm{Y} \text { weed free }} \times$ 100 (Grace, 1995), ability to withstand competition $(A W C)=$ $\left(\frac{\mathrm{Cbwf}}{\mathrm{Cbw}}\right) \times 100$, and ability to compete $(A C)=100-\left[\left(\frac{\mathrm{bw}}{\mathrm{bt}}\right) \times 100\right]$ (Szumigalski and Van Acker, 2005) indices were used to quantify the changes in competitive ability between safflower and weed. $Y_{\text {weed free }}$ is crop yield in weed free and $Y_{\text {weedy }}$ is crop yield in weedy condition. Weed biomass is bw and total plant biomass (crop and weed) is bt. Cbwf is crop biomass in weed free and Cbw is crop biomass in weedy condition. Furthermore, safflower seed yield, oil yield (soxhelt method according to Jensen, 2007), protein yield (semi micro-Kjeldahl digestion according to Bremner and Mulvaney, 1982), biological yield (total plant dry weight), and harvest index $(H I)=\frac{\text { Seed yield }}{\text { Biological yield }}$ were calculated. 


\section{Statistical analysis}

Differences between means were tested using the statistical program SAS 9.1 software (SAS Institute, 2003). Statistical tests performed include one-way analysis of variance (ANOVA) followed by Tukey's (HSD) test at $5 \%$ probability level (Little and Jackson, 1978) to determine whether there are any significant differences between the means of each treatment, assuming a normal distribution of the dependent variable data and homogeneity of variances. The effect of year and interaction between year and all treatments were not significant so the combined data were reported.

\section{Conclusion}

The present study provided new information about the common perception that timing of $\mathrm{N}$ fertilizer sources could change weed interference and yield response of safflower. Our findings showed that either $\mathrm{AN}$ or $\mathrm{U}$ fertilizer sources and timing pattern of $T_{1} N^{1} / 2, T_{2} N^{1} / 2$, and $T_{3} N_{0}$ not only increased safflower yield, but also enhanced weeds infestations. So, to enhance the productivity of safflower cropping and suppress weeds growth, use of $\mathrm{N}$ efficient management strategies like choice of variety, source and timing of $\mathrm{N}$ application adapted to site conditions, could be a remarkable growth strategy in safflower production and weeds control. Our results indicated that $U$ fertilizer timing of one third of the $\mathrm{N}\left(33.5 \mathrm{~kg} \mathrm{~N} \mathrm{ha}^{-1}\right)$ fertilization at sowing, two thirds of the $N(66.5 \mathrm{~kg} \mathrm{~N}$ ha-1) fertilization at stem elongation and zero $\mathrm{N}$ application at flowering $\left(T_{1} N^{1} / 3, T_{2} N^{2} / 3\right.$, and $\left.T_{3} N_{0}\right)$ can be used to advise farmers of the importance of strategic fertilizer management in terms of both weed management and safflower yield.

\section{Acknowledgements}

This project was funded by a grant from the Research Council and Graduate Center of Shiraz University, Shiraz, Iran.

\section{References}

Amy ES, Renner KA, Laboski C, Davis A (2008) Effect of fertilizer nitrogen on weed emergence and growth. Weed Sci. 56: 714-721.

Bagavan I, Ravikumar RL (2001) Strong undesirable linkages between seed yield and oil components: a problem in safflower improvement. Proceeding of the $5^{\text {th }}$ International Safflower Conference (pp. 103-107). USA.

Benech-Arnold RL, Sanchez RA, Forcella F, Kruck BC, Ghersa CM (2000) Environmental control of dormancy in weed seed banks in soil. Field Crops Res. 67: 105-122.

Berger A, Mcdonald AJ, Riha SJ (2007) Does soil nitrogen affect early competitive traits of annual weeds in comparison with maize? Weed Res. 47: 509-516.

Bergman J, Kandel H (2013) Safflower production [NDSU Extension Service]. Retrieved from:

<http://www.ag.ndsu.edu/pubs/plantsci/crops/a870.pdf> [accessed on 23 May 2014].
Blackshaw RE, Brandt RN, Janzen $H H$, Entz $T$, Grant CA, Derksen DA (2003) Differential response of weed species to added nitrogen. Weed Sci. 51: 532-539.

Blackshaw RE, Molnar LJ, Janzen HH (2004) Nitrogen fertilizer timing and application method affect weed growth and competition with spring wheat. Weed Sci. 52: 614-622.

Blackshaw RE, Brandt RN (2008) Nitrogen fertilizer rate effects on weed competitiveness is species dependent. Weed Sci. 56: 743-747.

Bremner JM, Mulvaney CS (1982) Total nitrogen. In: Page AL et al. editors. Methods of soil analysis. Part 2. $2^{\text {nd }}$ ed. Madison (WI), American Society of Agronomy.

Cheema MA, Saleem MF, Muhammad N, Wahid MA, Baber BH (2010) Impact of rate a timing of nitrogen application on yield and quality of canola (Brassica napus L.). Pak J Bot. 42: 1723-1731.

DiTomaso JM (1995) Approaches for improving crop competitiveness through the manipulation of fertilization strategies. Weed Sci. 43: 491-497.

Davis AS, Liebman M (2001) Nitrogen source influences wild mustard growth and competitive effect on sweet corn. Weed Sci. 49: 558-566.

Dordas CA, Sioulas C (2008) Safflower yield, chlorophyll content, photosynthesis, and water use efficiency response to nitrogen fertilization under rain fed conditions. Ind Crop Prod. 27: 75-85.

Grace JB (1995) On the measurement of plant competition intensity. Ecology. 76: 305-308.

Jensen WB (2007) The Origin of the Soxhelt Extractor. J Chem Educ. 84: 1913-1914.

Johnson RC, Ghorpade PB, Bradley VC (2001) Evaluation of the USDA core safflower collection for seven quantitative traits. $5^{\text {th }}$ International Safflower Conference (pp. 143-149). USA.

Johnson WG, Ott EJ, Gibson KD, Nielsen RL, Bauman TT (2007) Influence of nitrogen application timing on low density giant ragweed (Ambrosia trifida) interference in corn. Weed Technol. 21: 763-767.

Liebman M, Davis AS (2000) Integration of soil, crop and weed management in low-external-input farming systems. Weed Res. 40: 27-47.

Little TM, Jackson FJ (1978) Agricultural experimentation: design and analysis. Wiley, New York.

Muharnmad N, Cheerna MA, Wahid MA, Ahmad N, Zaman M (2007) Effect of source and method of nitrogen fertilizer application on seed yield and quality of canola (Brassica Napus L.). Pak J Agr Sci. 44: 74-78.

Mumera LM, Below FE (1993) Role of nitrogen in resistance to Striga parasitism in maize. Crop Sci. 33: 758-763.

Mundel HH, Blackshaw RE, Byers JR, Huang HC, Johnson DL, Keon R, Kubik J, McKenzie R, Otto B, Roth B, Stanford K (2004) Safflower production on the Canadian prairies. Retrieved from:

<http://safflower.wsu.edu/SafflowerProduction Canada.pdf $>$ Narits L (2010) Effect of nitrogen rate and application time to yield and quality of winter oilseed rape (Brassica napus L.). Agron Res. 20: 671-686. 
Osman EAM, El-Galad MA, Khatab KA, Zahran FAF (2014) Canola productivity as affected by nitrogen fertilizer sources and rates grown in calcareous soil irrigated with saline water. Glob J Sci Res. 2: 137-143.

Ozturk O (2010) Effects of source and rate of nitrogen fertilizer on yield, yield components and quality of winter rapeseed (Brassica napus L.). Chil J Agr Res. 70: 132-141.

Paschke MW, McLendon T, Redente EF (2000) Nitrogen availability and old-field succession in a short grass steppe. Ecosystems. 3: 144-158.

Rathke GW, Christen O, Diepenbrock W (2005) Effects of nitrogen source and rate on productivity and quality of winter oilseed rape (Brassica napus L.) grown in different crop rotations. Field Crops Res. 94: 103-113.

Sardi K, Beres I (1996) Effects of fertilizer salts on the germination of corn, winter wheat, and their common weed species. Commun Soil Sci Plan. 27: 1227-1235.
SAS Institute (2003) SAS users guide. SAS institute Inc., Cary, NC. USA.

Sheibani S, Ghadiri H (2012) Effect of split nitrogen fertilization and herbicide application on soil weed seed bank in wheat (Triticum aestivum L.) and oilseed rape (Brassica napus L.) rotation. J Biol Environ Sci. 6: 25-33.

Szumigalski A, Van-Acker R (2005) Weed suppression and crop production in annual intercrops. Weed Sci. 53: 813-825.

Terry RM, Marquardt PT, Camberato JJ, Johnson WG (2012) The Influence of nitrogen application timing and rate on volunteer corn interference in hybrid corn. Weed Sci. 60: 510-515.

Zoschke A, Quadranti M (2002) Integrated weed management: quo vadis? Weed Biol Manag. 2: 1-10. 